\title{
Hepatitis C Virus Infection Increases Fatigue in Health Care Workers
}

\author{
Vito Emanuele Catania ${ }^{1}$ (D), Giulia Malaguarnera ${ }^{2}$ (D, Giorgia Fiorenza ${ }^{2}$, \\ Eleonora Margherita Chisari ${ }^{3}$, Anna Rita Lipari ${ }^{4}$, Valentino Gallina ${ }^{4,5}$, \\ Manuela Pennisi ${ }^{6}$, Giuseppe Lanza ${ }^{7}$ (D) and Michele Malaguarnera ${ }^{2, *(D)}$ \\ 1 Department of Medical, Surgical Sciences and Advanced Technologies “G.F. Ingrassia”, \\ University of Catania, 95124 Catania, Italy; vito.catania@policlinico.unict.it \\ 2 "The Great Senescence" Research Centre, University of Catania, 95100 Catania, Italy; \\ giulia.malaguarnera@live.it (G.M.); giorgiaf1d@gmail.com (G.F.) \\ 3 Department of Education, University of Catania, 95100 Catania, Italy; g.chisari@tin.it \\ 4 SPRESAL ASP ENNA, 94100 Enna, Italy; arlipari@tiscali.it (A.R.L.); valentino.gallina@unikore.it (V.G.) \\ 5 Faculty of Engineering and Architecture-Risk analysis and work safety \\ organization-Kore University of Enna, 94100 Enna, Italy \\ 6 Department of Biomedical and Biotechnological Science, University of Catania, 95123 Catania, Italy; \\ manuela.pennisi@unict.it \\ 7 Department of Surgery and Medical-Surgical Specialties, University of Catania, 95123 Catania, Italy; \\ glanza@oasi.en.it \\ * Correspondence: michele.malaguarnera@gmail.com
}

Received: 28 August 2020; Accepted: 12 October 2020; Published: 15 October 2020

\begin{abstract}
Fatigue is a common state associated with a weakening or depletion of one's physical and mental resources, that leads to the inability to continue the individual functioning at a normal level of activity. Frequently, fatigue represents a response to infections, inflammation and autoimmune diseases. The scope of this study was to evaluate the fatigue in healthcare workers with and without hepatitis $\mathrm{C}$ virus (HCV) infection. Mental, physical and severity fatigue were evaluated through Krupp, Wessely and Powell fatigue scale. Anti-HCV antibodies, HCV RNA and HCV genotypes were also measured. Physical, mental and severity fatigue were higher in healthcare workers with HCV infection than the healthcare workers without infection $(p<0.01)$. Our data showed a direct link between fatigue and HCV infection in healthcare workers. Further studies are needed to evaluate $\mathrm{HCV}$ antiviral treatments on fatigue severity and on quality of life in healthcare workers
\end{abstract}

Keywords: HCV; fatigue; healthcare workers

\section{Introduction}

The World Health Organization (WHO) has reported that 71 million persons were living with chronic viral infection worldwide in 2015 [1]. Among these infections, viral hepatitis causes more than a million deaths each year. The global prevalence of hepatitis $\mathrm{C}$ virus (HCV) infection is estimated at $2.5 \%$, ranging from $2.9 \%$ in Africa to $1.3 \%$ in America [2]. The number of individuals chronically infected with HCV is estimated to be approximately 160 million, but most of them are unaware of their infection [3]. HCV infection has increasingly become a public health concern in developed and developing countries. Chronic HCV infection is the primary cause of hepatocellular carcinoma, which is one of the most common cancers and the third cause of cancer-related mortality worldwide [4].

Nowadays it is estimated that about $2 \%$ to $4 \%$ of the total number of hepatitis $C$ cases are healthcare workers who have suffered a needlestick injury and develop hepatitis as a result $[5,6]$. The estimated prevalence in UK primary care workers ranges from 0.6 to $2.6 \%$ while an independent 
working party, reporting to the IK Chief Medical Officer in 2002 suggested a UK population prevalence of $0.2-0.4 \%$ [7]. In 2007 Safe Work Australia reported that paramedics have the sixth highest rate of occupational injuries [8-10]. The principal routes of HCV infection were blood transfusion, unsafe injection procedures and intravenous drug use, but the most common causes reported are due to difficulties in operating the safety device and continued improper disposal of needles [11,12]. Currently screening of blood products for HCV has virtually eradicated transfusion-associated hepatitis C. Occupational exposure affects healthcare workers not only physically but also psychologically. In fact, healthcare workers are exposed not only to risk factors, including physical, chemical, accidentalities and related hazards also both psychosocial and organisational factors [13,14].

Fatigue is a complex and non-specific phenomenon characterized by self-reported tiredness or lack of energy, with a relevant impact on daily activities, social life and work performance [15]. It is also a common symptom in primary care workers [16]. Fatigue is difficult to characterize and define because it encompasses a complex interaction between biological, psychosocial and behavioural processes.

The prevalence of fatigue and its exacerbation known also as chronic fatigue syndrome is difficult to quantify due to the different criteria used $[17,18]$. It has been estimated to be between $0.24 \%$ [19] and $2.55 \%$ [20] among adults in the USA. Chronic fatigue syndrome prevalence is estimated at 0.3 to $1 \%$ among the public while its prevalence is almost twice as high among health care workers [21]. These workers gradually feel that they can no longer work effectively with their patients and feel difficulties in providing caring duties.

The most common types of fatigue are central (mental) and peripheral (physical). Central fatigue is characterized by a lack of self-motivation and can manifest both in physical and mental activities [22]. Peripheral fatigue is evidenced by neuromuscular dysfunction and muscle weakness [23]. There are many factor that influence fatigue such as age, culture, comorbidities, pain, mood, sleep, affect, anxiety and depression [24].

The pervasive and fluctuating nature of physical and emotional symptoms reduce work performance $[25,26]$. The quality of care giving services is decreased due to the higher probability of errors caused by occupational fatigue [27]. There is a complex interaction of predisposing precipitating and perpetuating factors in the aetiology of fatigue and support the hypothesis that pre-existing health issues, lack of fitness, distress and stress predisposes to be vulnerable to post infections fatigue. The risk occupational exposure to blood borne pathogens (including hepatitis B, hepatitis C and HIV) via sharps injuries, among health care workers is a challenging issue [28]. The aim of this study was to evaluate relationship between $\mathrm{HCV}$ and fatigue in health care workers.

\section{Patients and Methods}

The study was designed as a cross-sectional controlled study trial. It was performed at the research Centre of Senescence, University of Catania, and PRESAL ASP Enna, between February 2010 and July 2016. One thousand two hundred and fifty (1250) healthcare workers were enrolled of which 147 were excluded from the study. The subjects who did not authorize the use of their data were 103 and another 44 were excluded because they suffered from an autoimmune disease, anaemia or were HBV positive. The final number of healthcare worker were 1103, among them 82 healthcare workers were HCV+ (51 nurses, 16 medical technicians, one pharmacist, 14 physicians; Figure 1-flow chart). The control group consisted of health care workers without viral infection. The initial participants of these group were 1021, then 82 subjects were selected and matched for age and gender, occupational levels and care units in order to be comparable with the HCV group. The study included 164 healthcare workers: 82 with $\mathrm{HCV}$ infection and 82 without $\mathrm{HCV}$. HCV infection was confirmed by the presence of $\mathrm{HCV}$ RNA detected by polymerase chain reaction (PCR) using Cobas Amplicar testing. 


\section{0 healthcare workers}

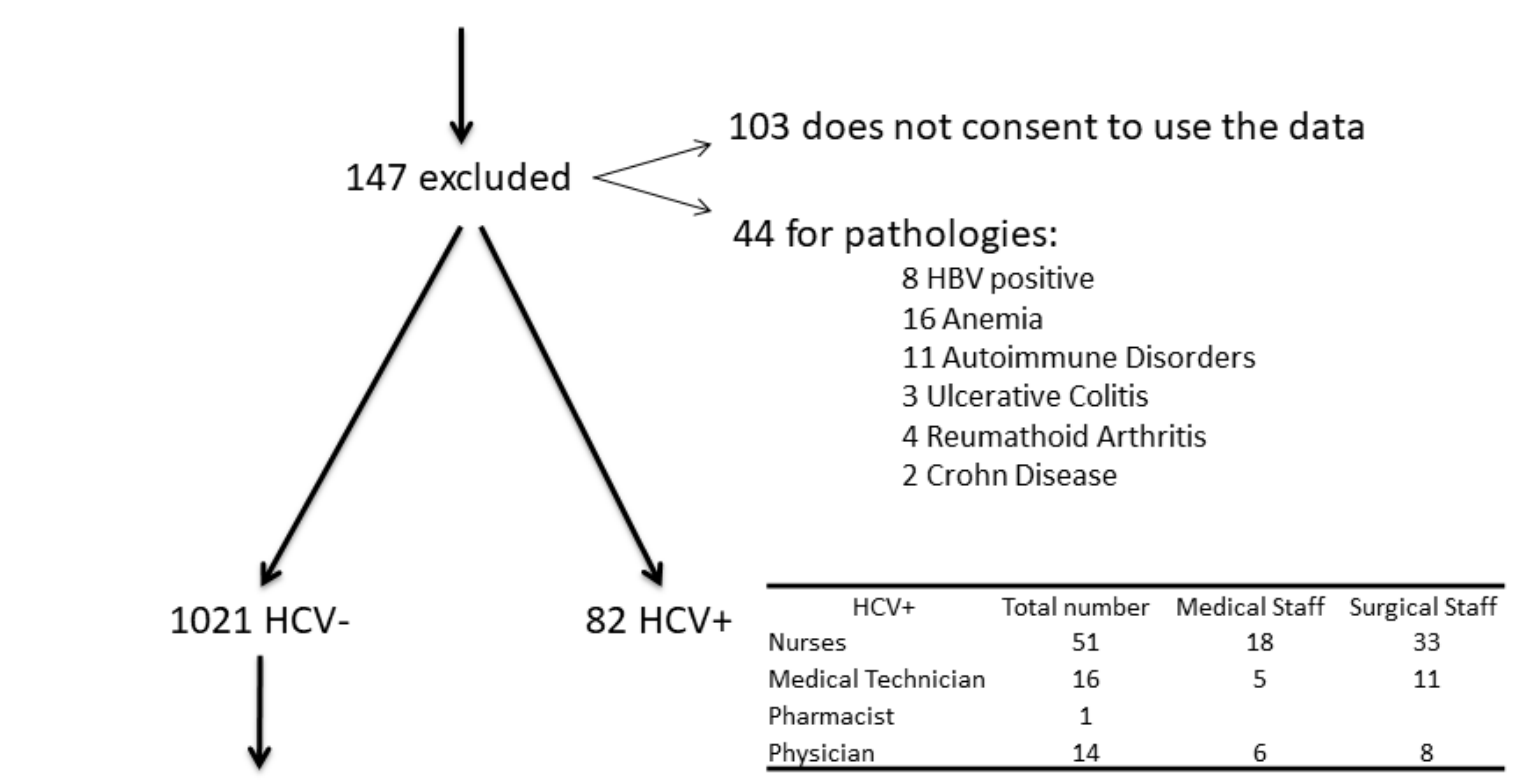

Selected as control $82 \mathrm{HCV}$ -

Figure 1. Flowchart.

A total of 164 healthcare workers aged 40 to 55 years were included in this study. The demographics and descriptive characteristic of recruited subjects are given in Table 1. Out of the 82 subjects with $\mathrm{HCV}$ infection 46 were females and 36 males, with an average age of $46.8 \pm 4.1$ years. Among the 82 controls, 46 were females and 36 were males, with an average age of $44.7 \pm 5.8$ years.

Table 1. Gender and lifestyle factors.

\begin{tabular}{cccccccc}
\hline & \multicolumn{2}{c}{ HCV N $\mathbf{~ 8 2}$} & \multicolumn{2}{c}{ NHCV N = 82 } & \multicolumn{2}{c}{ HCV vs. Not HCV } \\
\cline { 2 - 8 } & $\mathbf{N}$ & $\mathbf{\%}$ & $\mathbf{N}$ & $\mathbf{\%}$ & $\mathbf{9 5 \%}$ CI Odds Ratio & Signif. & $p$ \\
\hline Gender F/M & $46 / 36$ & 56.10 & $45 / 37$ & 54.88 & 0.5805 to 1.905 & NS & $>0.9999$ \\
Smokers Y/N & $50 / 32$ & 60.98 & $44 / 38$ & 53.66 & 0.7421 to 2.484 & NS & 0.4300 \\
Alcohol Y/N & $5 / 77$ & 6.10 & $7 / 75$ & 8.54 & 0.2401 to 2.118 & NS & 0.7657 \\
MS Single Y/N & $12 / 70$ & 14.63 & $10 / 72$ & 12.20 & 0.5250 to 3.103 & NS & 0.8193 \\
MS Married Y/N & $60 / 22$ & 73.17 & $56 / 26$ & 68.29 & 0.6617 to 2.470 & NS & 0.6069 \\
MS Divorce Y/N & $6 / 76$ & 7.32 & $10 / 72$ & 12.20 & 0.1954 to 1.522 & NS & 0.4308 \\
MS Widow Y/N & $4 / 78$ & 4.88 & $6 / 76$ & 7.32 & 0.2009 to 2.567 & NS & 0.7461 \\
\hline
\end{tabular}

$\mathrm{HCV}=$ Subjects with HCV virus; $\mathrm{NHCV}=$ Subjects without HCV; MS = Marital Status; $\mathrm{OL}=$ Occupational Level; NS $=$ Not Significant.

Subjects were required to fast over a period $>8 \mathrm{~h}$, follow a standard institutional protocol and were examined after a wash out period of three days. All the subjects were instructed to try to minimize stress variations (anxiety and depression).

The managers of the units granted permission to collect data and talked to healthcare workers in their units about this project. Eligible workers who wanted to participate were assigned a copy of the study questionnaire. They were instructed to fill it in within three days and return to a box provided for this purpose. The collected data did not contain any names, description or personal data that could identify any of these participants. The results were treated collectively due to the number of participants. The participants worked in different care units including the emergency department at the time of the study.

Previous unsuccessful therapy attempts with less effective treatment's protocols (e.g., IFN monotherapy) were not an exclusion criterion. All participants were seronegative for hepatitis B surface (HBs) antigen and for human immunodeficiency virus (HIV; type 1 and 2). 
$\mathrm{HCV}$-infected populations must have elevated serum alanine transaminase levels of more than 1.5 times upper normal limit and findings on liver biopsy consistent with chronic infection. Ineligible patients were those who had other liver diseases, as well as those who were affected by cancer, severe jaundice, pulmonary and renal chronic diseases, diabetes mellitus, hemoglobinopathies, pregnancy, prostatic and autoimmune diseases, cardiopathy, hemoglobinopathies, hemochromatosis, major depression or other severe psychiatric pathological conditions. None of the patients made excessive use of alcohol (> $20 \mathrm{~g} /$ day) or hepatotoxic drugs.

Clinical evaluations, hematochemical, virologic and instrumental were performed on these patients. The study was approved by ethical committee of "The Great Senescence" research centre.

All subjects underwent a physical examination and medical interview before treatment. Study recruitment was performed in observation and respect of the Helsinki Declaration. All participants gave their informed consent for the study participation and for each invasive procedure they underwent.

\subsection{Serum Analysis}

Venous blood samples were collected from all subjects enrolled in the study. Sera were separated, divided into aliquots and stored at $-80^{\circ} \mathrm{C}$ (until used). All patients underwent a complete virologic assay for HBV and HCV. Hepatitis B surface antigen (HBsAg), hepatitis B "core" IgG antibody (anti-HBc IgG), and hepatitis B "e" antigen (HBeAg), hepatitis B "e" antibody (HBeAb), hepatitis B virus DNA (HBV-DNA) and Delta virus antibody (anti-Delta) assays were performed. Anti-HCV antibodies were determined by enzyme-linked immunosorbent assay (ELISA) using assay kits (Ortho Diagnostic Systems, Raritan, NJ, USA). Hepatitis C virus RNA (HCV-RNA) levels were detected by polymerase chain reaction (PCR) of HCV-RNA 5" UTR using COBAS AmpliPrep/COBAS TaqMan (Roche Diagnostics Systems, Branchburg, NJ, USA). Serum samples negative for HCV RNA were retested using a more sensitive standardized qualitative PCR assay with a lower limit of detection of about $100 \mathrm{IU} / \mathrm{mL}$ to confirm HCV-RNA disappearance. HCV genotypes and subtypes were identified [29]. HCV viral genotypes were determined by restriction analysis of HCV-RNA 5"UTR [30]. Aspartate aminotransferase and alanine aminotransferase (AST and ALT), gamma glutamyl transferase $(\gamma \mathrm{GT})$, total, conjugated and unconjugated bilirubin, serum proteins analysis were performed. All liver function tests, hematochemical measurement and virologic analysis have been executed in the laboratory of our hospital using automated and standardized methods.

\subsection{Questionnaire Evaluating Fatigue}

All demographic and clinical data were collected and recorded by trained operators. Weight and height were measured without shoes. Body mass index (BMI) was calculated by the height squared in meters $\left(\mathrm{Kg} / \mathrm{m}^{2}\right)$. The participants also completed a self-reported questionnaire.

Fatigue severity was measured by the fatigue severity scale (FSS). The FSS is a self-assessed nine-question scale, each item ranging from 1 (strongly disagree with the statement) to 7 (maximum agreement). Here, the total score ranged from 9 to 63 , and it was directly related to the severity observed on the nine-item fatigue questionnaire [31]. The Wessely's test and Powell's test were used to examine mental and physical fatigue, respectively. Their scores consisted of a total list of 14 questions, divided in two scales measuring physical fatigue (eight items scored from 0 (no fatigue) to 2 (highest possible fatigue), total score range 0-16); and mental fatigue (five items, total score range 0-10) [32-34]

\subsection{Statistical Analysis}

Data were described as mean \pm standard deviation (SD) for normally distributed variables and analyzed by unpaired two tailed $t$-tests. Proportion were valued with Fisher's exact test and $95 \% \mathrm{CI}$ of odds ratio (OR) with the Baptista-Pike method. A $p$ value $<0.05$ was evaluated as statistically significant. Data were analyzed using the GraphPad Prism 8 statistical software package (8.4.2 Macintosh Version; GraphPad Software, San Diego, CA, USA). 


\section{Results}

The demographics and descriptive characteristic of the recruited subjects are given in Tables 1 and 2. The comparison of clinical parameters between health care workers with and without HCV is shown in Table 2.

Table 2. Demographics and clinical characteristics. Summary $p$ value: ${ }^{* *}<0.005 ;{ }^{* * *}<0.0001$.

\begin{tabular}{|c|c|c|c|c|c|c|c|}
\hline & \multicolumn{2}{|c|}{ HCV N = 82} & \multicolumn{2}{|c|}{ Not HCV N = 82} & \multicolumn{3}{|c|}{ HCV vs. not HCV } \\
\hline & Mean & SD & Mean & SD & $95 \% \mathrm{CI}$ & Significance & $p$ \\
\hline Age (years) & 46.8 & 4.1 & 44.7 & 5.8 & -3.649 to -0.5511 & ** & 0.0021 \\
\hline Sistolic Art Press (mmHg) & 137.1 & 9.4 & 138.2 & 8.7 & -1.693 to 3.893 & NS & 0.4877 \\
\hline Diastolic Art press (mmHg) & 81.4 & 9.1 & 80.6 & 9.2 & -3.622 to 2.022 & NS & 0.9219 \\
\hline $\mathrm{HR}(\mathrm{bpm})$ & 70.2 & 9.6 & 72.8 & 8.7 & -0.2253 to 5.425 & NS & 0.3775 \\
\hline BMI $\left(\mathrm{Kg} / \mathrm{m}^{2}\right)$ & 24.2 & 2.9 & 24 & 3.1 & -1.126 to 0.7257 & NS & 0.5497 \\
\hline HCV RNA & 3.5 & 0.9 & 0 & 0 & -3.696 to -3.304 & $* * * *$ & $<0.0001$ \\
\hline HCV exposure (years) & 11.2 & 3.2 & / & / & & & \\
\hline Anti HCV Ab & \multicolumn{2}{|c|}{ positive } & \multicolumn{2}{|c|}{ negative } & & & \\
\hline HCV genotypes & & & & & & & \\
\hline $1 \mathrm{a}$ & 10 & I & 1 & I & & & \\
\hline $1 b$ & 69 & 1 & 1 & I & & & \\
\hline $2 \mathrm{a}$ & 1 & 1 & 1 & I & & & \\
\hline $2 b$ & 2 & 1 & 1 & 1 & & & \\
\hline
\end{tabular}

The healthcare workers with HCV showed higher levels of urea (95\% CI 0.58 to $5.22 \mathrm{mg} / \mathrm{dL}$ ), AST (95\% CI -131.1 to $-120.9 \mathrm{IU} / \mathrm{L})$, ALT (95\% CI -140.7 to $-126.7 \mathrm{IU} / \mathrm{L}), \mathrm{CRP}$ (95\% CI -4.90 to $-4.26 \mathrm{mg} / \mathrm{L})$ $(p<0.0001)$, total cholesterol (95\% CI -9.12 to $-0.88 \mathrm{mg} / \mathrm{dL})$, HDL cholesterol (95\% CI -4.23 to -0.37 $\mathrm{mg} / \mathrm{dL})$, and triglycerides $(95 \% \mathrm{CI}-9.22$ to -0.98$)(p<0.05)$ and lower levels of glucose $(95 \%$ CI 0.58 to $5.22 \mathrm{mg} / \mathrm{dL}$ ) (Table 3).

Table 3. Laboratory parameters.

\begin{tabular}{|c|c|c|c|c|c|c|c|}
\hline & \multicolumn{2}{|c|}{ HCV N $=82$} & \multicolumn{2}{|c|}{ Not HCV N $=82$} & \multicolumn{3}{|c|}{ HCV vs. Not HCV } \\
\hline & Mean & SD & Mean & SD & $95 \%$ CI & Signif. & $p$ \\
\hline Urea $\mathrm{mg} / \mathrm{dL}$ & 44.1 & 3.7 & 38.1 & 4.1 & 0.5829 to 5.217 & $* * * *$ & $<0.0001$ \\
\hline Glucose mg/dL & 74.2 & 8.7 & 77.1 & 6.1 & 0.5829 to 5.217 & * & 0.0145 \\
\hline Total Cholesterol mg/dL & 225 & 12.8 & 220 & 13.9 & -9.121 to -0.8794 & * & 0.0177 \\
\hline HDL Cholesterol mg/dL & 44.1 & 6.2 & 41.8 & 6.3 & -4.228 to -0.3724 & * & 0.0197 \\
\hline Triglycerides mg/dL & 190.1 & 12.8 & 185 & 13.9 & -9.221 to -0.9794 & * & 0.0156 \\
\hline AST IU/L & 164.2 & 22.9 & 38.2 & 3.9 & -131.1 to -120.9 & $* * * *$ & $<0.0001$ \\
\hline ALT IU/L & 169.8 & 32.1 & 36.1 & 3.4 & -140.7 to -126.7 & $* * * *$ & $<0.0001$ \\
\hline CRP mg/L & 6.25 & 1.44 & 1.67 & 0.36 & -4.904 to -4.256 & $* * * *$ & $<0.0001$ \\
\hline
\end{tabular}

The comparison of mental, physical and severity fatigue in healthcare worker with and without HCV infection is expressed in Table 4. Physical fatigue was higher of 3.2 score in HCV subjects than in health workers without HCV infection (95\% CI -4.21 to $-2.19 ; p<0.0001)$, mental fatigue was higher 1.8 score than in health workers without HCV infection (95\% CI -2.76 to $-0.84 ; p=0.0003)$. Fatigue severity was higher 13.9 score respect subjects without HCV infection (95\% CI - 16.38 to - 11.42; $p<0.0001)$. 
Table 4. Fatigue results.

\begin{tabular}{cccccccc}
\hline & \multicolumn{2}{c}{ HCV N $\mathbf{8 2}$} & \multicolumn{2}{c}{ Not HCV N = 82 } & \multicolumn{2}{c}{ HCV vs. Not HCV } \\
\cline { 2 - 8 } & Mean & SD & Mean & SD & 95\% CI & Signif. & $p$ \\
\hline Physical fatigue & 11.4 & 2.9 & 8.2 & 3.6 & -4.208 to -2.192 & $* * * *$ & $<0.0001$ \\
Mental Fatigue & 9.7 & 3.4 & 7.9 & 2.8 & -2.761 to -0.8395 & $* * *$ & 0.0003 \\
Fatigue Severity & 49.1 & 6.7 & 35.2 & 9.2 & -16.38 to -11.42 & $* * * *$ & $<0.0001$ \\
\hline \multicolumn{8}{c}{ Summary $p$ value: ${ }^{* * *}<0.001 ; * * * * 0.0001}$.
\end{tabular}

\section{Discussion}

HCV positive healthcare workers showed higher fatigue score severity both mental and physical than subjects without HCV infections. Fatigue is a multi-factorial symptom that may be influenced by a variety of demographic, medical, psychosocial, behavioral and biological factors. It has a negative impact on work, social relationship, mood and daily activities and causes significant impairment in overall quality of life. This cross-sectional study confirms the negative impact of HCV infection on physical and mental fatigue $(p<0.01)$ in healthcare worker. Fatigue at work may be associated with decreased vigilance, motivation work capability and performance.

HCV infection leads to chronic liver diseases, such as cirrhosis and hepatocellular carcinoma (HCC). Hepatitis $\mathrm{C}$ infection has a negative impact on patients' quality of life both physically, mentally, emotionally and socially; the effects of hepatitis $C$ extend far beyond liver-related morbidity [35]. In our study, we observed that the HCV positive healthcare workers showed an increase of fatigue. Fatigue severity does not appear to correlate with the biochemical parameters and the subtypes of hepatitis $C$ viruses. Other potential contributing factors include medical comorbidities, medications, nutritional issues, physical deconditioning, mood disturbance and physical symptoms, among others. Fatigue may be influenced by age, culture, comorbidities, pain, mood, sleep and affects [24]. This suggest that several contextual factors may influence the experience of this symptom [36]. Fatigue is a major related factor in healthcare, directly affecting performance, care giving and decision making, resulting in a breakdown in relations between the healthcare and patients, family and team members. It increases mistakes in the administration of medicines and has an impact on practices involving patient monitoring [37,38]. Several studies suggest that people with HCV may have a lower quality of life due to depression, chronic fatigue, fibromyalgia and anxiety in comparison to the general population. Previous studies indicate an increase of depression score, anxiety and fatigue in non-treated HCV patients $[39,40]$. The disorders above result in higher rates of risking-taking behaviour among the infected when left untreated, thus representing a danger not only to patients themselves, but also to the healthy population.

Fatigue in liver disease is recognised as prevalent and persistent. The liver is central to the pathogenesis of peripheral and central fatigue, which in our view is dependent upon energy regulation and crosstalk between the gut, liver, muscle and brain. The liver is connected to extra-hepatic tissues in order to signal energy needs (skeletal muscle, brain), storage (adipose tissue) and substrate (gut). The liver communicates with extra-hepatic tissue, and with respect to fatigue it communicates through neuronal and hormonal networks.

Different studies suggest that people with HCV may have a lower quality of life due to depression, chronic fatigue and anxiety in comparison to the general population [41,42] Moreover, there is evidence that displays how HCV may affect the central nervous system by generating inflammatory cytokines and toxic substances in the liver that generate symptoms of fatigue and other behavioural changes via alterations in neural processes [43-45].

The toxic substances that can be produced include ones like nitric oxide and stimulating amino acids (aspartates and gentamates) which induce neuronal apoptosis and also neurosteroids that activate inhibitory brain pathways $[46,47]$. It is plausible that inflammatory cytokines serve as mediators of the both environmental and genetic factors that may trigger the development of depressive disorders. 


\section{Conclusions}

The cross-sectional nature of this study prevented the establishment of a causal relationship between variables and represents a potential limitation. Therefore, longitudinal studies should be conducted in the future.

The continuous development of health care delivery will be accompanied by the evaluation of new occupational hazards, so to minimize occupational exposure, there is the necessity to implement effective protective measures [48]. The overall impact of HCV treatment with more efficacious and effective direct-acting antiviral (DAA) therapies may be useful for evaluate the direct and indirect role of HCV infections on fatigue [49].

Author Contributions: Conceptualization, G.M. and M.M.; Data curation, V.E.C., G.M., M.P. and M.M.; Formal analysis, V.E.C., G.M., A.R.L. and M.P.; Investigation, V.E.C., G.M., G.F., E.M.C., A.R.L., V.G., M.P., G.L. and M.M.; Methodology, V.E.C. and M.M.; Supervision, M.M.; Writing-original draft, V.E.C. and M.M.; Writing-review \& editing, M.M. All the authors contributed to the writing, reading and giving of final approval to the version to be published. Each author agreed to be accountable for all aspects of the work in ensuring that questions related to the accuracy or integrity of any part of the work are appropriately investigated and resolved. All authors have read and agreed to the published version of the manuscript.

Funding: There was no funding provided for the research or publication of the manuscript.

Conflicts of Interest: The authors declare no conflict of interest.

\section{References}

1. WHO. Who Global Hepatitis Report; WHO: Geneva, Switzerland, 2017; ISBN 9789241565455.

2. Petruzziello, A.; Marigliano, S.; Loquercio, G.; Cozzolino, A.; Cacciapuoti, C. Global epidemiology of hepatitis $C$ virus infection: An up-date of the distribution and circulation of hepatitis $C$ virus genotypes. World J. Gastroenterol. 2016, 22, 7824-7840. [CrossRef] [PubMed]

3. Lavanchy, D. Evolving epidemiology of hepatitis C virus. Clin. Microbiol. Infect. 2011, 17, 107-115. [CrossRef]

4. Hanafiah, K.M.; Groeger, J.; Flaxman, A.D.; Wiersma, S.T. Global epidemiology of hepatitis C virus infection: New estimates of age-specific antibody to HCV seroprevalence. Hepatology 2013, 57, 1333-1342. [CrossRef] [PubMed]

5. Rogers, B.; Goodno, L. Evaluation of interventions to prevent needlestick injuries in health care occupations. Am. J. Prev. Med. 2000, 18, 90-98. [CrossRef]

6. King, K.C.; Strony, R. Needlestick; StatPearls Publishing: Treasure Island, FL, USA, 2020.

7. Sharpe, M. The report of the Chief Medical Officer's CFS/ME working group: What does it say and will it help? Clin. Med. 2002, 2, 427-429. [CrossRef] [PubMed]

8. Reichard, A.A.; Marsh, S.M.; Moore, P.H. Fatal and Nonfatal Injuries Among Emergency Medical Technicians and Paramedics. Prehosp. Emerg. Care 2011, 15, 511-517. [CrossRef] [PubMed]

9. Roberts, M.H.; Sim, M.R.; Black, O.; Smith, P. Occupational injury risk among ambulance officers and paramedics compared with other healthcare workers in Victoria, Australia: Analysis of workers' compensation claims from 2003 to 2012. Occup. Environ. Med. 2015, 72, 489-495. [CrossRef]

10. Maguire, B.J.; O'Meara, P.; Brightwell, R.F.; O’Neill, B.J.; Fitzgerald, G. Occupational injury risk among Australian paramedics: An analysis of national data. Med. J. Aust. 2014, 200, 477-480. [CrossRef]

11. Webster, D.P.; Klenerman, P.; Dusheiko, G.M. Hepatitis C. Lancet 2015, 385, 1124-1135. [CrossRef]

12. Schuurmans, J.; Lutgens, S.; Groen, L.; Schneeberger, P. Do safety engineered devices reduce needlestick injuries? J. Hosp. Infect. 2018, 100, 99-104. [CrossRef]

13. Markovic-Denic, L.; Maksimović, N.; Marusic, V.; Vucicevic, J.; Ostric, I.; Đurić, D. Occupational exposure to blood and body fluids among health-care workers in Serbia. Med. Princ. Pract. 2015, 24, 36-41. [CrossRef] [PubMed]

14. Cooke, C.E.; Stephens, J.M. Clinical, economic, and humanistic burden of needlestick injuries in healthcare workers. Med. Devices Evid. Res. 2017, 10, 225-235. [CrossRef] [PubMed]

15. Pennisi, M.; Malaguarnera, G.; Di Bartolo, G.; Lanza, G.; Bella, R.; Chisari, E.M.; Cauli, O.; Vicari, E.; Malaguarnera, M. Decrease in Serum Vitamin D Level of Older Patients with Fatigue. Nutrients 2019, 11, 2531. [CrossRef] [PubMed] 
16. Hamilton, W.; Watson, J.; Round, A. Rational testing: Investigating fatigue in primary care. BMJ 2010, 341, 502-504. [CrossRef]

17. Larun, L.; Brurberg, K.G.; Odgaard-Jensen, J.; Price, J.R. Exercise therapy for chronic fatigue syndrome. Cochrane Database Syst. Rev. 2019, 4, CD003200. [CrossRef]

18. Gates, M.; Wingert, A.; Featherstone, R.; Samuels, C.; Simon, C.; Dyson, M.P. Impact of fatigue and insufficient sleep on physician and patient outcomes: A systematic review. BMJ Open 2018, 8, e021967. [CrossRef]

19. Reyes, M.; Nisenbaum, R.; Hoaglin, D.C.; Unger, E.R.; Emmons, C.; Randall, B.; Stewart, J.A.; Abbey, S.; Jones, J.F.; Gantz, N.; et al. Prevalence and Incidence of Chronic Fatigue Syndrome in Wichita, Kansas. Arch. Intern. Med. 2003, 163, 1530-1536. [CrossRef]

20. Reeves, W.C.; Jones, J.F.; Maloney, E.; Heim, C.; Hoaglin, D.C.; Boneva, R.S.; Morrissey, M.; Devlin, R. Prevalence of chronic fatigue syndrome in metropolitan, urban, and rural Georgia. Popul. Health Metr. 2007, 5, 5. [CrossRef]

21. Alavi, N.M.; Madani, M.; Sadat, Z.; Kashani, H.H.; Sharif, M.R. Fatigue and Vitamin D Status in Iranian Female Nurses. Glob. J. Health Sci. 2015, 8, 196-202. [CrossRef]

22. Taylor, J.L.; Amann, M.; Duchateau, J.; Meeusen, R.; Rice, C.L. Neural contributions to muscle fatigue: From the brain to the muscle and back again. Med. Sci. Sports Exerc. 2016, 48, 2294-2306. [CrossRef]

23. Gandevia, S.C.; Allen, G.M.; Neering, I.R.; Middleton, J.; Jones, R. Strength, voluntary drive, and endurance during isometric contractions in prior polio subjects. Ann. N. Y. Acad. Sci. 1995, 753, 408-409. [PubMed]

24. Zalai, D.; Sherman, M.; McShane, K.; Shapiro, C.M.; Carney, C.E. The importance of fatigue cognitions in chronic hepatitis C infection. J. Psychosom. Res. 2015, 78, 193-198. [CrossRef]

25. Malaguarnera, G.; Pennisi, M.; Gagliano, C.; Vacante, M.; Malaguarnera, M.; Salomone, S.; Drago, F.; Bertino, G.; Caraci, F.; Nunnari, G.; et al. Acetyl-L-Carnitine Supplementation during HCV Therapy with Pegylated Interferon- $\alpha 2 b$ Plus Ribavirin: Effect on Work Performance; A Randomized Clinical Trial. Hepat. Mon. 2014, 14, e11608. [CrossRef]

26. Komaroff, A.L. Variability in medical practice: An investigative opportunity for general medicine. J. Gen. Intern. Med. 1986, 1, 31-34.

27. Rassouli, M.; Zandiye, S.; Noorian, M.; Zayeri, F. Fatigue and Its Related Factors in Pediatric and Adult Oncology Nurses. Iran. J. Nurs. 2011, 24, 37-47.

28. Nobile, C.G.A.; Montuori, P.; Diaco, E.; Villari, P. Healthcare personnel and hand decontamination in intensive care units: Knowledge, attitudes, and behaviour in Italy. J. Hosp. Infect. 2002, 51, 226-232. [CrossRef] [PubMed]

29. Knodell, R.G.; Ishak, K.G.; Black, W.C.; Chen, T.S.; Craig, R.; Kaplowitz, N.; Kiernan, T.W.; Wollman, J. Formulation and application of a numerical scoring system for assessing histological activity in asymptomatic chronic active hepatitis. Hepatology 1981, 1, 431-435. [CrossRef] [PubMed]

30. Beck, A.T.; Steer, R.A.; Carbin, M.G. Psychometric properties of the Beck Depression Inventory: Twenty-five years of evaluation. Clin. Psychol. Rev. 1988, 8, 77-100. [CrossRef]

31. Krupp, L.B.; Larocca, N.G.; Muir Nash, J.; Steinberg, A.D. The fatigue severity scale: Application to patients with multiple sclerosis and systemic lupus erythematosus. Arch. Neurol. 1989, 46, 1121-1123. [CrossRef]

32. Wessely, S.; Powell, R. Fatigue syndromes: A comparison of chronic "postviral" fatigue with neuromuscular and affective disorders. J. Neurol. Neurosurg. Psychiatry 1989, 52, 940-948. [CrossRef]

33. Chalder, T.; Berelowitz, G.; Pawlikowska, T.; Watts, L.; Wessely, S.; Wright, D.; Wallace, E.P. Development of a fatigue scale. J. Psychosom. Res. 1993, 37, 147-153. [CrossRef]

34. Pistone, G.; Marino, A.D.; Leotta, C.; Dell'Arte, S.; Finocchiaro, G.; Malaguarnera, M. Levocarnitine administration in elderly subjects with rapid muscle fatigue: Effect on body composition, lipid profile and fatigue. Drugs Aging 2003, 20, 761-767. [CrossRef] [PubMed]

35. Yamini, D.; Basseri, B.; Chee, G.M.; Arakelyan, A.; Enayati, P.; Tran, T.T.; Poordad, F. Tobacco and other factors have a negative impact on quality of life in hepatitis C patients. J. Viral Hepat. 2011, 18, 714-720. [CrossRef] [PubMed]

36. Bower, J.E. Cancer-related fatigue-mechanisms, risk factors, and treatments. Nat. Rev. Clin. Oncol. 2014, 11, 597-609. [CrossRef] [PubMed]

37. Steege, L.M.; Pinekenstein, B.J.; Rainbow, J.G.; Arsenault Knudsen, É. Addressing Occupational Fatigue in Nurses: Current State of Fatigue Risk Management in Hospitals, Part 2. J. Nurs. Adm. 2017, 47, 484-490. [CrossRef] 
38. Arimura, M.; Imai, M.; Okawa, M.; Fujimura, T.; Yamada, N. Sleep, mental health status, and medical errors among hospital nurses in Japan. Ind. Health 2010, 48, 811-817. [CrossRef]

39. Neri, S.; Pistone, G.; Saraceno, B.; Pennisi, G.; Luca, S.; Malaguarnera, M. L-carnitine decreases severity and type of fatigue induced by interferon- $\alpha$ in the treatment of patients with hepatitis C. Neuropsychobiology 2003, 47, 94-97. [CrossRef]

40. Malaguarnera, G.; Bertino, G.; Chisari, G.; Motta, M.; Vecchio, M.; Vacante, M.; Caraci, F.; Greco, C.; Drago, F.; Nunnari, G.; et al. Silybin supplementation during HCV therapy with pegylated interferon- $\alpha$ plus ribavirin reduces depression and anxiety and increases work ability. BMC Psychiatry 2016, 16, 398. [CrossRef]

41. Barreira, D.P.; Marinho, R.T.; Bicho, M.; Fialho, R.; Ouakinin, S.R.S. Psychosocial and Neurocognitive Factors Associated With Hepatitis C-Implications for Future Health and Wellbeing. Front. Psychol. 2019, 9, 9. [CrossRef]

42. Modabbernia, A.; Poustchi, H.; Emalekzadeh, R. Neuropsychiatric and Psychosocial Issues of Patients with Hepatitis C Infection: A Selective Literature Review. Hepat. Mon. 2013, 13, 13. [CrossRef]

43. Dantzer, R.; Connor, J.C.; Freund, G.G.; Johnson, R.W.; Kelley, K.W. From inflammation to sickness and depression: When the immune system subjugates the brain. Nat. Rev. Neurosci. 2008, 9, 46-56. [CrossRef]

44. Haroon, E.; Raison, C.L.; Miller, A.H. Psychoneuroimmunology Meets Neuropsychopharmacology: Translational Implications of the Impact of Inflammation on Behavior. Neuropsychopharmacology 2012, 37, 137-162. [CrossRef]

45. Bürgel, B.; Friesland, M.; Koch, A.; Manns, M.P.; Wedemeyer, H.; Weissenborn, K.; Schulz-Schaeffer, W.J.; Pietschmann, T.; Steinmann, J.; Ciesek, S. Hepatitis C virus enters human peripheral neuroblastoma cells-evidence for extra-hepatic cells sustaining hepatitis C virus penetration. J. Viral Hepat. 2010, 18, 562-570. [CrossRef]

46. Malaguarnera, G.; Vacante, M.; Drago, F.; Bertino, G.; Motta, M.; Giordano, M.; Malaguarnera, M. Endozepine-4 levels are increased in hepatic coma. World J. Gastroenterol. 2015, 21, 9103-9110. [CrossRef] [PubMed]

47. Perry, W.; Hilsabeck, R.C.; Hassanein, T.I. Cognitive Dysfunction in Chronic Hepatitis C: A Review. Dig. Dis. Sci. 2008, 53, 307-321. [CrossRef] [PubMed]

48. van Wijk, P.T.L.; Pelk-Jongen, M.; Wijkmans, C.; Voss, A.; Timen, A.; Schneeberger, P.M. Variation in interpretation and counselling of blood exposure incidents by different medical practitioners. Am. J. Infect. Control 2008, 36, 123-128. [CrossRef] [PubMed]

49. Bertino, G.; Ardiri, A.; Proiti, M.; Rigano, G.; Frazzetto, E.; Demma, S.; Ruggeri, M.I.; Scuderi, L.; Malaguarnera, G.; Bertino, N.; et al. Chronic hepatitis C: This and the new era of treatment. World J. Hepatol. 2016, 8, 92-106. [CrossRef] [PubMed]

Publisher's Note: MDPI stays neutral with regard to jurisdictional claims in published maps and institutional affiliations.

(C) 2020 by the authors. Licensee MDPI, Basel, Switzerland. This article is an open access article distributed under the terms and conditions of the Creative Commons Attribution (CC BY) license (http://creativecommons.org/licenses/by/4.0/). 